\title{
Cornelia de Lange Syndrome with Hypernatremia: Two Case Reports
}

\author{
Ece Kurul1 , (D) Soner Sazak1, (D) ibrahim Bektaşoğlu1', (D) Hasan Dursun² \\ 1 University of Health Sciences Turkey, Prof. Dr. Cemil Taşçığlu City Hospital, Clinic of Child Health and Diseases, Istanbul, Turkey \\ 2 University of Health Sciences Turkey, Prof. Dr. Cemil Taşşıoğlu City Hospital, Clinic of Child Health and Diseases, Division of Pediatric Nephrology, \\ istanbul, Turkey
}

\section{Abstract}

Cornelia de Lange syndrome (CdLS), is a genetical syndrome which can be seen as hereditary, or sporadically. Characteristical appearance is very crucial for diagnosis. Although almost all patient shave characteristical face appearance, depending on the severity of the cases, some accompanying symptoms could be skeletal and extremity defects, gastrointestinal system diseases, central nervous system anomalies and related diseases, genitourinary system anomalies, or heart defects, vision and hearing problems. In this paper, two patients with holoprosencephaly and recurrent episodes of hypernatremia are minded us to reconsider CdLS as a differential diagnosis of hypernatremia. We also point out some important steps in the treatment of the hypernatremia.

Keywords: Cornelia de Lange syndrome, hypernatremia, holoprosencephaly

\section{INTRODUCTION}

Cornelia de Lange syndrome (CdLS), also known as Brachmann de Lange syndrome, was first as reported by W. Brachmann in 1916, and it was described by CdLS in 1933 (1). CdLS has been defined as a syndrome that includes microcephaly, synophysis (lush and thick, curved eyebrows in the midline), long lashes, deep orbital arch, small and blunt nose, antevert nostrils, long philtrum, thin upper lip, wide-spaced small teeth, small chin, big ears, posterior or low anterior hairline, bushy hair, distinctive phenotypic features, mental retardation or learning disabilities, intrauterine growth retardation, prematurity, retardation of postnatal growth and development, developmental anomalies of hands and feet, widespread or regional hypertrichosis, heart defects, eye and genitourinary anomalies, hearing loss, gastro esophageal dysfunction (2,3). According to phenotypic properties, type 2, CdLS classic type (type 1) and mild type (type 2) have been identified. Type 2, which shows mild phenotypic characteristics, has a better prognosis than the classical type $(2,4,5)$. Two cases presenting with hypernatremia and diagnosed with CdLS were presented here.

\section{CASE PRESENTATIONS}

\section{Case 1}

The eleven-month-old girl was admitted to the pediatric emergency outpatient clinic with symptoms of vomiting, coughing, wheezing and weakness. Twenty five-year-old mother's follow-up without problems as the first baby after 41 weeks of uncomplicated pregnancy by cesarean section and she weighted 4,000 gr. It was learned that she had a convulsion on the second day after birth and stayed in the neonatal intensive care unit for 2 months due to the neonatal jaundice.

When she applied to the clinic, the general condition was mediumbad, severe dehydrated appearance, turgor tone decreased, Glasgow Coma score 11 , fever $37^{\circ} \mathrm{C}$, respiratory rate $50-55 / \mathrm{min}$, pulse $146 / \mathrm{min}$, blood pressure $60 / 45 \mathrm{mmHg}, \mathrm{SpO}_{2}=98$ (\% with

Phone: +90 5378872157 E-mail: ecekurul@yahoo.com ORCID ID: orcid.org/0000-0003-4248-005X

Cite this article as: Kurul E, Sazak S, Bektaşoğlu I, Dursun H. Cornelia de Lange Syndrome with Hypernatremia:

Two Case Reports. Eur Arch Med Res 2020;36(3):218-21

${ }^{\circ}$ Copyright 2020 by the University of Health Sciences Turkey, Prof. Dr. Cemil Taş̧ıŏlu City Hospital

European Archives of Medical Research published by Galenos Publishing House. 
$21 \mathrm{O}_{2}$ ), and the capillary filling time was under 3 seconds. On physical examination, facial appearance characteristic of CdLS compatible with synophris, long eyelashes, blunt nose, antevert nose, big ears, low hairline, and bushy hair, small discrete teeth, micrognathia, hypertrichosis, transfers lines in palms were seen (Figure 1). Body weight $7.5 \mathrm{~kg}(<3 \mathrm{p})$, height $68 \mathrm{~cm}(<3 \mathrm{p})$, head circumference $42.5 \mathrm{~cm}$ (median of first age), pulse rate as 110 per minute and respiration rate as 23 per minute were measured. On arrival, the patient's routine laboratory tests received hemoglobin $8.5 \mathrm{~g} / \mathrm{dL}$ (11 to $16 \mathrm{~g} / \mathrm{dL}$, hematocrit 34.3\% (37-54\%), leukocyte $33.000 \mu \mathrm{L}(4-103 \mu \mathrm{L})$, platelet $601,000 \mathrm{~mm}^{3}(100,000$ $300,000 \mathrm{~mm}^{3}$ ), glucose $152 \mathrm{mg} / \mathrm{dL}$ (74-106 mg/dL), urea: $172 \mathrm{mg} /$ $\mathrm{dL}(8.4$ and $25.8 \mathrm{mg} / \mathrm{dL}$ ) creatinine $1.76 \mathrm{mg} / \mathrm{dL}$ (0.31 to $0.98 \mathrm{mg} /$ $\mathrm{dL}$ ), sodium $186 \mathrm{mEq} / \mathrm{L}$ (136-146 mEq/L), potassium $6.6 \mathrm{mEq} / \mathrm{L}$ (3.5-5.1 mEq/L), C-reactive protein $40 \mathrm{mg} / \mathrm{L}(<5 \mathrm{mg} / \mathrm{L})$, fractional excretion of sodium 0.14\%, pH: 7.23 (7.35-7.45), $\mathrm{pCO}_{2}: 55 \mathrm{mmHg}$ (35-48 mmHg), $\mathrm{HCO}_{3} 20 \mathrm{mEq} / \mathrm{L}(22.5-26.9 \mathrm{mEq} / \mathrm{L}), \mathrm{pO}_{2} 55 \mathrm{mmHg}$ (83-108 $\mathrm{mmHg})$, base deficit -5 were detected in blood gas. The patient was admitted for further examination and treatment, and intravenous fluid treatment was initiated by admitting severe hypernatremic dehydration. Desmopressin $\mathrm{HCl}$ was started by considering the syndrome-induced central diabetes insipitus due to high urine output, hypernatremic dehydration attacks in the past history, low urine density and high sodium in the follow-up. On the third day of treatment, blood sodium, urea

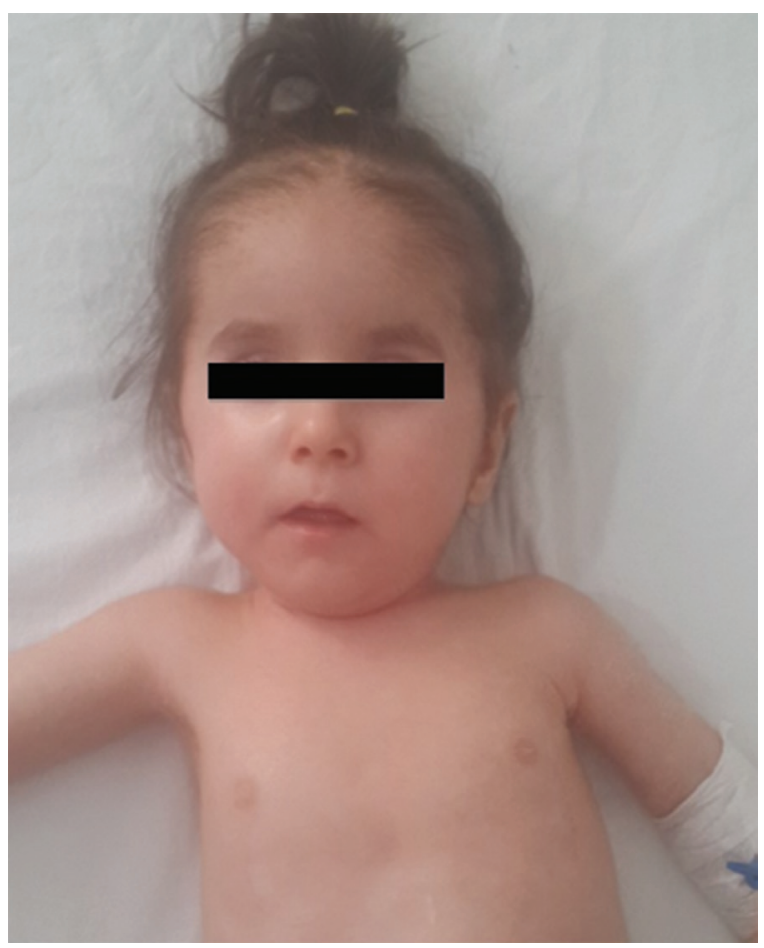

Figure 1. In case 1, Cornelia de Lange phenotypic features such as synophysis, long eyelashes, blunt snout, antevert nostrils, long philtrum, thin upper lip, wide-spaced small teeth, micrognathy, bushy hair and creatinine values returned to normal limits. The patient was discharged after scheduled outpatient follow-up.

\section{Case 2}

A five-and-a-half-year-old girl was referred to the pediatric nephrology outpatient clinic due to an increase in serum sodium values. The patient was born from the first pregnancy of the 31-year-old mother, born with cesarean as $4.500 \mathrm{gr}$ in the term, there was no kinship between the parents, and she was treated for hypernatremia at the centers where she applied due to complaints of fatigue, inability to move her feet, and tendency to sleep when she was four months old. It was learned that cranial computed tomography and magnetic resonance examinations revealed holoprosencephaly, that she was treated for hypernatremia in the intensive care unit of another hospital before she was admitted to our outpatient clinic and was discharged the day before.

Body weight was measured at $10,250 \mathrm{~kg}(<3 \mathrm{p})$, height $87 \mathrm{~cm}(<3$ p), head circumference $46 \mathrm{~cm}$ (1.5 median median) pulse rate was 110 per minute and breath count was 23 per minute. In his physical examination, synophrosis, long eyelashes, blunt nose, antevert nostrils, big ears, low forehead hairline, bushy hair, small split teeth, micrognathia, hypertrichosis, and transverse lines were seen in the palm (Figure 2). There was no walking and speaking, but he could understand simple sentences. Oral

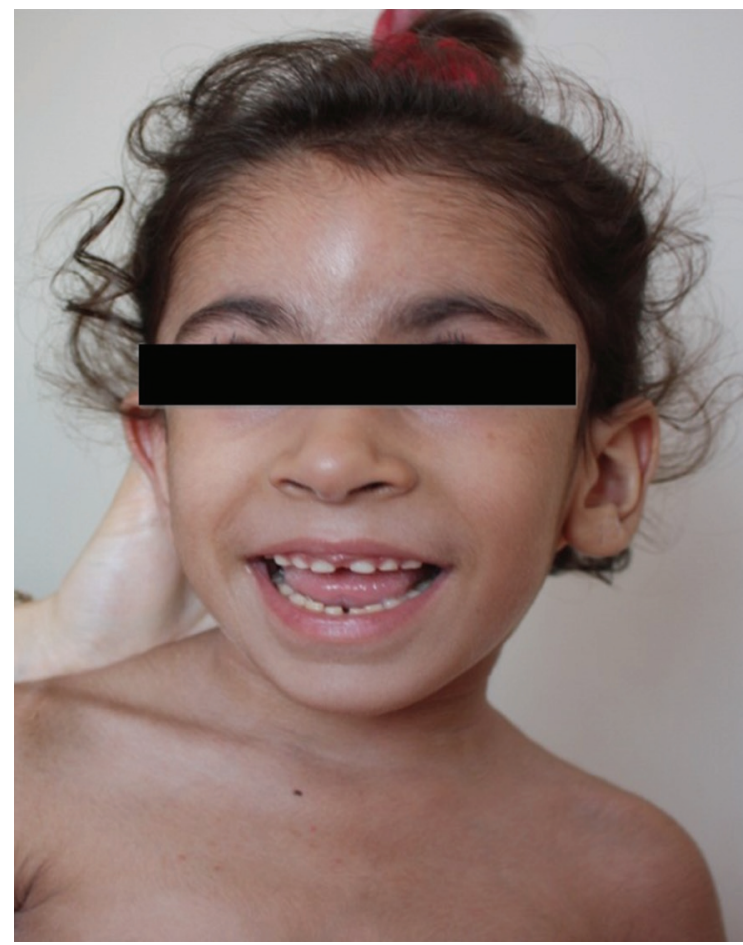

Figure 2. In case 2, Cornelia de Lange phenotypic features such as synophysis, long eyelashes, blunt nose, antevert nostrils, long philtrum, thin upper lip, wide-spaced small teeth, micrognathy, bushy hair 
mucosa was dry, skin turgor was impaired and there were evident signs of dehydration. Mild tachycardia was present in the cardiovascular system examination. Respiratory system and abdominal examination were normal.

Serum sodium level $162 \mathrm{mEq} / \mathrm{L}$ (136-146 mEq/L), antidiuretic hormone (ADH) level $0.5 \mathrm{pmol} / \mathrm{L}(0.0-13 \mathrm{pmol} / \mathrm{L})$ and creatinine level $0.55 \mathrm{mg} / \mathrm{dL}(0.31-0.98 \mathrm{mg} / \mathrm{dL})$ were detected in laboratory studies. Urine creatinine levels were $127 \mathrm{mg} / \mathrm{dL}$ (40-278 mg/ $\mathrm{dL})$ and sodium $41 \mathrm{mEq} / \mathrm{L}(20-69 \mathrm{mEq} / \mathrm{L})$. Fractional sodium excretion was $0.12 \%$. Serum osmolarity was $335 \mathrm{mOsm} / \mathrm{L}$ (275$295 \mathrm{mOsm} / \mathrm{L})$. With these findings, hypernatremia due to CdLS and prosencephaly were considered. Intravenous and oral fluid treatment was initiated and serum sodium values returned to normal limits on the second day of treatment. The patient has been discharged. Seven days later, when she came to the checkup, hypernatremia (serum sodium $162 \mathrm{mEq} / \mathrm{L}$ ) was found to have recurred and the family did not provide the recommended liquid. The patient was again given intravenous and oral fluid treatment and serum sodium levels were restored to normal. The family was given genetic counseling, but genetic mutation analysis could not be done and the patient was discharged with oral hydration and serum sodium levels were stable during the sixth month of follow-up.

\section{DISCUSSION}

CdLS is a syndrome that is often diagnosed with characteristic facial appearance, and it is not common in the literature to have holoprosencephaly and surviving cases such as those presented in the case (3-6). Holoprosencephaly is an anomaly resulting from the inability of dividing the prosencephalon bilaterally to form the cerebral hemispheres. Patients with holoprosencephaly who have severe and complex anomalies die in the intrauterine period, and the incidence of living holoprosencephaly cases has been reported as 12/100,000 (2). Some of the complications of holoprosencephaly are adipsy, hypopituitarism, diabetes insipitus, neurogenic hypernatremia, and patients are therefore able to apply with the clinical picture of hypernatremic dehydration $(7,8)$. Our patients also have hypernatremia episodes due to dehydration.

A mutation in the Nipped-B-like protein gene has been reported on the $5^{\text {th }}$ chromosome in $50 \%$ of typical cases (type 1). Furthermore, the $X$-transitive form of the syndrome (type 2) has been reported to occur with a mutation in structural maintenance of chromosomes protein 1A (SMC1A) gene on the $10^{\text {th }}$ chromosome, and the type 3 form has been reported to occur with a mutation in the SMC3 gene on the $10^{\text {th }}$ chromosome
$(9,10)$. For this reason, although chromosome and gene mutation analysis were not performed on our patients, families were given genetic counseling.

When plasma osmolarity in hypernatremia rises to $285 \mathrm{mOsm} /$ $\mathrm{kg}$, the first physiological response is increased ADH secretion and a feeling of thirst. These mechanisms do not work in infants, unconscious patients, or in cases where the brain does not develop, such as in our patients, so water retention or water intake in the kidneys can not be increased. When sodium intake increases, fractional sodium excretion icreases while hypernatremic dehydration decreases (11-13). In these cases, fractional sodium excretion of $0.14 \%$ and $0.12 \%$ support nonrenal fluid loss. In hypernatremic dehydration, the clinical signs are mostly due to water and electrolyte imbalance between the body's liquid compartments. These patients are presented with various clinical statements such as convulsions, lethargy, hyperthermia, coma and encephalopathy. When sodium concentration is gradually increased in the blood, neurons synthesize a number of substances that raise intracellular osmotic pressure, called "idiogenic osmol", to prevent the loss of water going through the cell to the blood $(12,13)$. Since serum sodium values were chronically high in our cases, serum sodium values reached $170 \mathrm{mEq} / \mathrm{L}$, but central nervous system findings such as lethargy, coma were not observed.

Adipsy is a disease characterized by the absence of thirst sensation despite dehydration or excess of salt, which can be one of the rare causes of hypernatremic dehydration $(11,12)$. The first physiological stimuli for thirst are increased osmolarity and hypovolemia. Osmoreceptors in the anterior wall of the third ventricle, the osmotic regulator of thirst, stimulate ADH secretion from the anterior hypothalamus. This warning is known as osmotic thirst. Any congenital or acquired lesion affecting the anterior hypothalamus or third ventricle can cause loss of sensation of thirst. These patients are presented with a combination of adipsy and central diabetes insipidus (11-13). ADH secretion may be unaffected, partially affected or completely affected in adipside. Rarely, some children may experience adipsia without a structural lesion. Although there was a structural abnormality in our cases, serum ADH value was within normal limits.

\section{CONCLUSION}

As a result, CdLS should be considered in patients with mental retardation, suspicious dysmorphic facial appearance and recurrent episodes of hypernatremia, care should be taken in their treatment and most importantly, the family should 
be informed to ensure that the patient does not become dehydrated.

\section{Ethics}

Informed Consent: Oral consent has been obtained from the patient and her relatives.

Peer-review: Externally peer-reviewed.

\section{Authorship Contributions}

Concept: H.D., Design: S.S., I.B., Data Collection or Processing: H.D., E.K., Analysis or Interpretation: H.D., E.K., Literature Search: H.D., E.K., Writing: H.D., E.K.

Conflict of Interest: No conflict of interest was declared by the authors.

Financial Disclosure: The authors declared that this study received no financial support.

\section{REFERENCES}

1. Bishun NP, Morton WR. Brachmann/de Lange Syndrome. Lancet 1965;1:439.

2. Jones KL. Brachmann de Lange Syndrome (Cornelia de Lange Syndrome). In: Smith's recognizable patterns of humanmal formation: Smith's. 6th ed. California: School of Medicine La Jolla 2006;82-7.

3. Kline AD, Barr M, Jackson LG. Growth manifestations in the Brachmannde Lange syndrome. Am J Med Genet 1993;47:1042-9.
4. Uçar \$̦, Altınel E, Zorlu P, Şahin G, Çiftçi A, Karacan C. Cornelia de Lange Sendromu: İki Olgu. Yeni Tıp Dergisi 2008;25:118-20.

5. Kaba S, Doğan M, Bala KA, Demir N, Üstyol L, Doğan S. Cornelia de lange sendromu: Bir olgu sunumu. Tıp Araștırmaları Dergisi 2012;10:109-12.

6. Akil İ, Yüksel H, Gözmen S, Tarhan S. Hypernatremic dehydration and renal vein thrombosis in a case with Cornelia de Lange syndrome associated with holoprosencephaly. Erciyes Medical Journal 2004;26:201-5.

7. Blaas HG, Eriksson AG, Salvesenn KA, Isaksen CV, Christengen B, Møllerløkken $G$, et al. Brains anda faces in holoprosencephaly: re and postnatal description of 30 cases. Ultrasound Obstet Gynecol 2002;19:24-38.

8. Kawame H, Kurosawa K, Akatsuka A, Ochiai Y. [Clinical spectrum and management of holoprosencephaly]. No to Hattatsu = Brain and Development 2000;32:301-6.

9. Musio A, Selicorni A, Focarelli ML, Gervasini C, Milani D, Russo S, et al. X-linked Cornelia de Lange syndrome owing to SMC1L1 Mutations. NatGenet 2006;38:528-30.

10. Mannini L, Cucco F, Quarantotti V, Krantz ID, Musio A. Mutation spectrum and genotype-phenotype correlation in cornelia de lange syndrome. Hum Mutat 2013;34:1589-96.

11. Sinha A, Ball S, Jenkins A, Hale J, Cheetham T. Objective assessment of thirst recovery in patients with adipsic diabetes insipidus. Pituitary 2011;14:307-11.

12. Hayek A, Peake GT. Hypothalamic adipsia with out demonstrable structural lesion. Pediatrics 1982;70:275-8.

13. Yamamoto T, Shimizu M, Fukuyama J, Yamaji T. Pathogenesis of extracellular fluid abnormalities of hypothalamic hypodipsiahypernatremia syndrome. Endocrinol Jpn 1988;35:915-24. 